
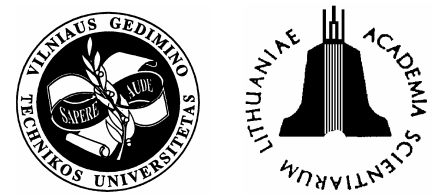

\title{
EXPERIMENTAL INVESTIGATION INTO FIRE RESISTANCE OF HC-FST COLUMNS UNDER AXIAL COMPRESSION
}

\author{
Žygimantas Blaževičius ${ }^{1}$, Audronis Kazimieras Kvedaras ${ }^{2}$ \\ Dept of Steel and Timber Structures, Vilnius Gediminas Technical University, \\ Saulètekio al. 11, LT-10223 Vilnius, Lithuania \\ E-mail: ${ }^{1}$ zygiui@centras.lt, ${ }^{2}$ akve@st.vtu.lt \\ Received 1 June 2006; accepted 2 Oct 2006
}

\begin{abstract}
A certain amount of analytical methods for determining fire resistance of concrete filled steel tubular columns are developed. Mostly those methods refer to or have as an origin the data about the results of real experiments. The research work on this kind of composite column behaviour under fire conditions with a wide range of different parameters measuring was performed. The behaviour of 16 axially loaded HC-FST (hollow concrete filled steel tubular) columns without fire protection under conditions similar to ISO-834 fire and under normal conditions was experimentally investigated and the results are presented in this paper. The experimental values of fire resistance were measured and the failure mode was determined for 4 axially loaded columns. And for the comparison of test parameters, 4 axially loaded HC-FST columns were tested under normal conditions. In addition, 8 hollow concrete-filled steel tubular stub columns and 4 hollow concrete tubular stub columns under normal conditions were tested. The final objective was to prepare experimental data for analysis and to find some analytical dependence between test parameters with the most significant influence on the fire results of HC-FST columns.
\end{abstract}

Keywords: experimental investigation, axial loading, concrete-filled steel tubular columns, load bearing capacity, fire resistance.

\section{Introduction}

The use of HC-FST (Hollow Concrete-Filled Steel Tubular) columns has become widespread in the countries, where it is used for building tall buildings. The presence of load bearing concrete within a hollow steel column has a beneficial effect on the fire resistance of the steel section. In many cases the required period of fire resistance can be obtained by concrete filling without the need for external protection.

Some researches $[1,2]$ were performed to find assumptions or initial data necessary for creating methods to determine the fire resistance of C-FST columns. Some information about this kind of experiments - testing course and the results is given in [3,4]. The comparison [5] of the results obtained using different analytical calculation methods shows quite a significant difference. The simple empirical expression for determination of HC-FST column compressive resistance under fire conditions is given in [6]. Some analytical expressions for analysing HC-FST column work under fire conditions is given in [7]. The method for prediction of fire resistance of HCFST columns and based on the results of laboratory tests is presented in [8].

There is still a need for right and real experiments to collect more experimental research data and to develop more accurate calculation methods for the fire design of composite structures. Thus, the main objectives of the experimental program and this paper are threefold: 1) to describe a series of tests on composite columns exposed to standard fire and subjected to axial load, 2) to develop a mechanics model for HC-FST columns exposed to standard fire, 3) to prepare experimental data for analysis of the influence of the changing sectional dimension of column - thickness of the hollow concrete core on the fire resistance of structure.

\section{The object of experimental studies}

Experiments intended for determining the resistance of structures to mechanical effects under heat conditions, and heat-involving in-place experiments in general are specific and require special equipment, preparation and methods. Due to their complexity, similar studies (involving natural-size building constructions) in Lithuania and the neighbouring countries are carried out but seldom.

The object of the experimental studies is loadcarrying capacity under axial compression and the behaviour of HC-FST elements with a hollow centrifugal concrete core under ambient conditions and at elevated temperatures. Thus two types of tests were carried out: „I“ - determination of compressive resistance of an HCFST or HC specimen loaded with axial load under normal ambient conditions, "II" - determination of HC-FST specimen fire resistance under axial load and elevated temperature conditions. In pursuance of the study programme $20 \mathrm{HC}-\mathrm{FST}$ and HC (hollow concrete) specimens were tested under ambient and elevated temperatures. The 

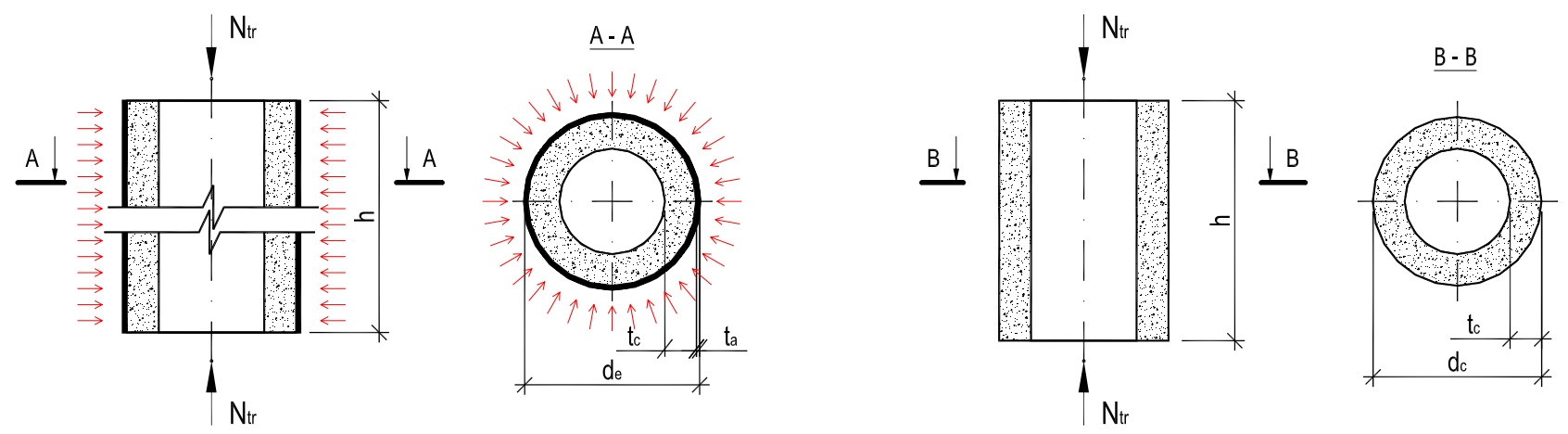

Fig 1. HC-FST and HC specimens

specimens were manufactured by cutting long columns. These columns consisted of steel pipes welded with a spiral weld, inside which a hollow concrete core was formed by centrifuging. The outer diameter of the steel pipe was $219 \mathrm{~mm}$, and the wall thickness was about $1,6 \mathrm{~mm}$. The centrifuged concrete core of the columns from which the HC-FST and HC specimens were cut, was of variable thickness: at the opposite ends of the column the thickness of the concrete core varied between 46 and $17 \mathrm{~mm}$. The initial length of the elements was up to $5,5 \mathrm{~m}$, their age was approx 15 years by keeping them under outdoor conditions without additional protective measures against steel corrosion and concrete erosion.

12 short $(300 \mathrm{~mm})$ and 12 long $(2000 \mathrm{~mm}) \mathrm{HC}-\mathrm{FST}$ elements were fabricated by cutting them from the initial length elements. It was intended to test 4 long $(2000 \mathrm{~mm})$ HC-FST specimens for compressive resistance under ambient conditions and 4 long HC-FST specimens for fire resistance. Also 8 short HC-FST specimens of 12 were used to determine their resistance to axial compression, whereas 4 of them were used to produce concrete rings, which were also tested to define concrete resistance to axial compression. HC-FST and HC specimens under consideration are shown in Fig 1.

\section{Preparation of specimens}

The cutting machine with a special abrasive discs was used for cutting the initial length HC-FST elements to shorter ones. During cutting, the initial-length HC-FST elements were laid on cylindrical guides, which rotated the tubular element round its axis in respect to the rotating cutting disc. The above-mentioned equipment ensured the perpendicularity of the ending cross-section. For cutting the steel shell and the concrete core, cutting discs designed for cutting steel and concrete of the same thickness respectively were used. Disparities on the specimen edges remaining after cutting were removed by grinding with an abrasive disc until even bearing surfaces (with a tolerance of $0,2 \mathrm{~mm}$ ) were formed. The column cutting machine is shown in Fig 2.

In order to determine the mechanical characteristics of steel, 16 standard steel specimens were prepared and tested for draught resistance. The specimens were produced from the steel shell of the parts of HC-FST. The manufacturing and testing the specimens were carried out in compliance with the requirements applicable to such tests according to a standard [9]. In order to determine the mechanical characteristics of concrete, 4 short HC specimens were manufactured by removing the steel shell from HC-FST elements and cutting them to the foreseen length. The geometrical parameters of HC-FST and HC specimens and intended type of testing are in Table 1.

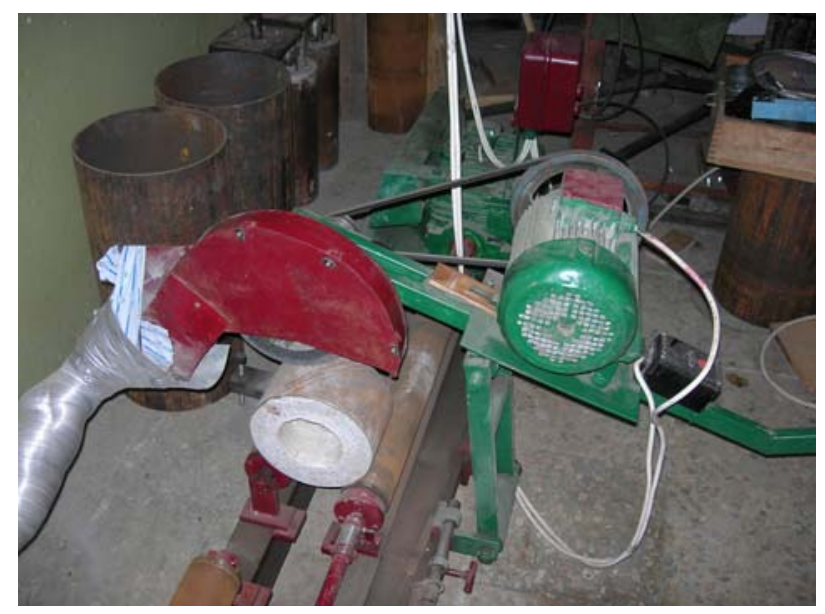

Fig 2. Cutting machine used for preparing the specimens

\section{Test equipment and procedures}

All the specimens for the experiment were prepared, and the tests were carried out in the laboratories of the Faculty of Civil Engineering of Vilnius Gediminas Technical University in accordance with the requirements $[10,11]$, as it was possible to do. The longitudinal load of the HC-FST and HC specimens was created by a hydraulic jack with a capacity of 500 tons and with a 3-ton measuring scale. The heat conditions were created by the electrical furnace "Utena" designed and manufactured specifically for tests for combustibility and fire resistance of building constructions with natural geometrical parameters. The furnace chamber has a floor area of $400 \mathrm{~mm}$ $\mathrm{x} 400 \mathrm{~mm}$ and is of $1400 \mathrm{~mm}$ high. The interior faces of the chamber are lined with an insulating material-caolin wool plates. And the electric spiral collars are embedded in vertical plates of caolin with the interval of $5 \mathrm{~cm}$ beside the surface, closer to the furnace chamber. The furnace temperature is measured by three inner platinum-rhodium 
Table 1. Geometrical parameters of HC-FST and HC specimens

\begin{tabular}{|c|c|c|c|c|c|c|}
\hline No & Type of the cross-section & Code of the specimen & $h[\mathrm{~mm}]$ & $t_{a}[\mathrm{~mm}]$ & $t_{c, \text { mean }}[\mathrm{mm}]$ & Type of the test \\
\hline 1 & HC-FST & $1 \mathrm{II}$ & 2004 & 1,65 & 20,1 & $\mathrm{I}$ \\
\hline 2 & HC-FST & $3 \mathrm{I} 2$ & 2000 & 1,6 & 31,9 & $\mathrm{I}$ \\
\hline 3 & HC-FST & $5 \mathrm{I} 1$ & 1999 & 1,63 & 24,875 & $\mathrm{I}$ \\
\hline 4 & HC-FST & $2 \mathrm{I} 2$ & 1992 & 1,6 & 28,9 & $\mathrm{I}$ \\
\hline 5 & HC-FST & $1 \mathrm{~T} 1$ & 300 & 1,65 & 23,6 & $\mathrm{I}$ \\
\hline 6 & HC-FST & $2 \mathrm{~T} 2$ & 298,5 & 1,6 & 25,5 & $\mathrm{I}$ \\
\hline 7 & HC-FST & $2 \mathrm{~T} 1$ & 298 & 1,6 & 15,9 & I \\
\hline 8 & HC-FST & $3 \mathrm{~T} 1$ & 298 & 1,6 & 16,15 & $\mathrm{I}$ \\
\hline 9 & HC-FST & $3 \mathrm{~T} 2$ & 298 & 1,6 & 16,55 & I \\
\hline 10 & HC-FST & 4T1 & 298 & 1,63 & 19,025 & $\mathrm{I}$ \\
\hline 11 & HC-FST & $5 \mathrm{~T} 1$ & 296 & 1,63 & 24,375 & $\mathrm{I}$ \\
\hline 12 & HC-FST & 0T1 & 295 & 1,6 & 15,65 & $\mathrm{I}$ \\
\hline 13 & $\mathrm{HC}$ & 0TB2 & 296,5 & 1,6 & 21,9 & $\mathrm{I}$ \\
\hline 14 & $\mathrm{HC}$ & 1TB2 & 296 & 1,65 & 21,6 & I \\
\hline 15 & $\mathrm{HC}$ & 4TB2 & 300 & 1,63 & 20,875 & $\mathrm{I}$ \\
\hline 16 & $\mathrm{HC}$ & $5 \mathrm{~TB} 2$ & 300 & 1,63 & 20,375 & I \\
\hline 17 & HC-FST & $0 \mathrm{I} 1$ & 1999 & 1,6 & 27,15 & II.1 \\
\hline 18 & HC-FST & $0 \mathrm{I} 2$ & 2000,5 & 1,6 & 20,65 & II. 2 \\
\hline 19 & HC-FST & $2 \mathrm{I} 1$ & 2003 & 1,6 & 20,9 & II.1 \\
\hline 20 & HC-FST & $4 \mathrm{I} 2$ & 2000 & 1,63 & 33,725 & II.1 \\
\hline \multicolumn{7}{|c|}{$\begin{array}{l}\text { NOTES } \\
\text { 1. The cross-sections of all the HC-FST and HC specimens are hollow and round-shaped. The outer diameter of the HC-FST } \\
\text { specimens: } 219 \mathrm{~mm} \text {. The outer diameter of the HC specimens: } 215,8 \mathrm{~mm} \text {. } \\
\text { 2. The meanings of the markings in the Table columns: } h \text { - element length; } t_{a}-\text { steel shell thickness; } t_{c, \text { mean }}-\text { mean thickness of } \\
\text { the concrete ring of the element. } \\
\text { 3. Test type marking and test type description: } \\
\text { - „I“ - determination of the compressive strength whether the HC-FST or HC specimens are under axial loading and } \\
\text { normal ambient conditions; } \\
\text { - "II.1“- fire resistance determination of the HC-FST specimens under } 25 \text {-ton axial load and ISO } 834 \text { fire conditions; } \\
\text { - „II.2“ - fire resistance determination of the HC-FST specimens under } 18 \text {-ton axial load and ISO } 834 \text { fire conditions. }\end{array}$} \\
\hline
\end{tabular}

thermocouples that were also embedded in the kaolin insulation of chamber. According to the defined programme and the indications of inner thermocouples, the temperature regime is maintained and automatically adjusted with the aid of heating controller PROTERM 100. This controller can regulate temperature in three levels of the furnace chamber: top, middle height and bottom levels. The temperatures measured by three inner thermocouples were averaged automatically and the average temperature was used as the criterion for controlling the furnace temperature.

\subsection{Test under normal conditions - type I test}

Equipment for type I test. 4 short $\mathrm{HC}, 4$ short HC-FST and 4 long HC-FST specimens were prepared for type I test. The specimens ends were rested against rigid steel press plates of $50 \mathrm{~mm}$ thickness, fixed in the press body via a hinged support. Between the ends of the specimen and press plates, aluminium spacers were placed (they were cut from medium-hard aluminium sheet of $1 \mathrm{~mm}$ thickness). The fixing scheme of the specimen ensured the articulating the support and uniform application of the pressure to the relatively even ground (with a tolerance of $0,2 \mathrm{~mm}$ ) bearing cross-section of the element.

For strain measuring of the specimens, 8 PKB-type, 50-mm basis length strain-gauge transducers each were attached to the outer surface of the HC and HC-FST elements in the middle part of the height. 4 transducers were attached to the specimen in the vertical direction for measuring longitudinal deformations, and 4 transducers in the horizontal direction for measuring transversal deformations. The transducers were connected with the universal data acquisition system ALMEMO 5590-2.

For measuring horizontal displacements of the middle part of the HC-FST specimens, electronic displacement indicators were used. They were also connected to the universal data acquisition system ALMEMO 5590-2 and fixed independently of the specimen and the press. The specimen fixing scheme is given in Fig 3.

The process and measuring of type I test. In respect of every specimen, the concentricity of the load was checked before applying a breaking load to the specimen. The specimens centring was effected by applying a load equal to up to $30 \%$ of the expected load-bearing capacity and by comparing the readings of the strain-gauge 


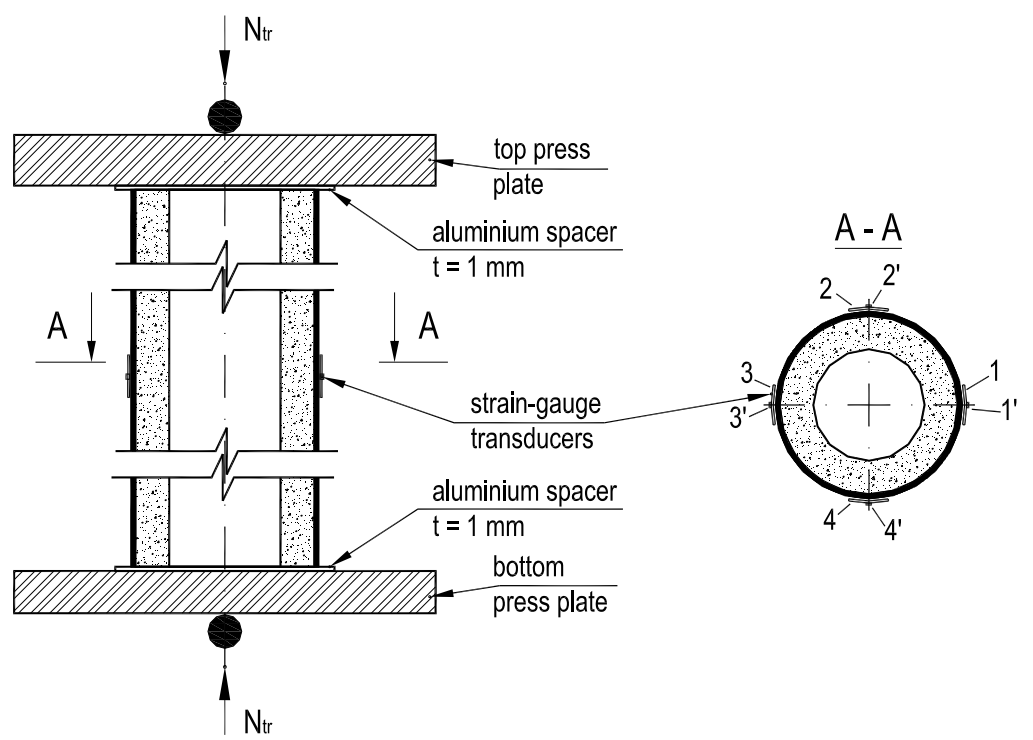

Fig 3. The specimen fixing scheme for type I test

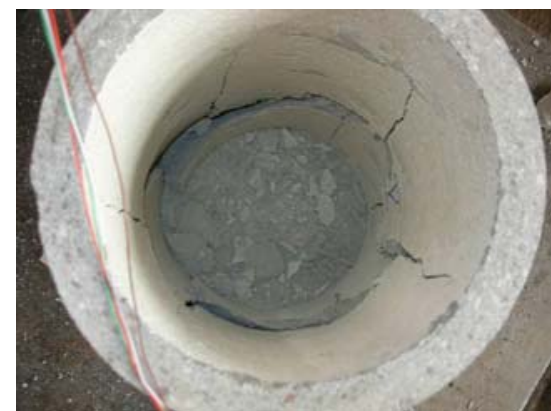

a)

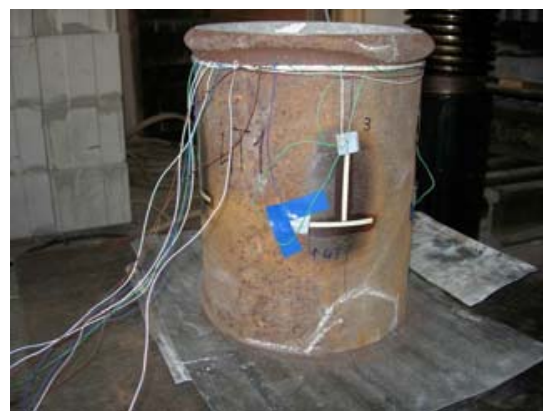

b)

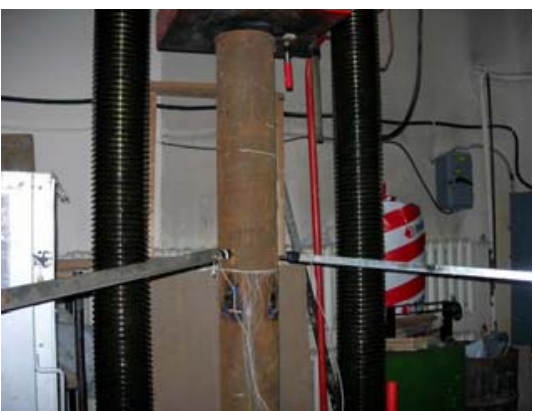

c)

Fig 4. Specimens tested under ambient conditions: a) HC-type specimen after testing; b) short HC-FST-type specimen after testing; c) long HC-FST-type specimen during the test

transducers measuring strain. In case of large differences in the readings of strain-gauge transducers attached to the opposite sides of the element, the specimen supporting point was adjusted accordingly. After centring the specimen, the load was increased and the measuring was carried out from the beginning (at the load value of 0 0,5 ton). The average speed of load application was $2,0 \mathrm{kN} / \mathrm{min}$. The load was increased gradually in 3-ton stages, whereas the readings of the strain-gauge transducers and displacement measuring devices were recorded at every stage of the load. Under the conditions of a load next to the strength limit of the specimen, the readings of the strain-gauge transducers and the shear measuring devices were recorded every $0,5-1,0$ ton. All specimens were subjected to testing until they collapsed.

The standard steel specimens were tested by a 250 $\mathrm{kN}$-capacity traction machine available at the laboratory of the Dept of Steel and Timber structures of the VGTU. The compressive resistance of concrete was determined on the basis of the test results of 4 short HC specimens.

Experimental results and specimens behaviour during the test under ambient conditions. The $\mathrm{HC}$ specimen failure occurs after developing longitudinal cracks in the hollow concrete core. The failure mode of both short and long HC-FST type specimens is quite similar. The speci- mens lost their load-bearing capacity upon local buckling of the thin-walled steel shell and the hollow concrete core at the ends of the specimen at one of the press plates. The specimens 5T2 (with parameters $L / t_{c} / t_{s}-296 \mathrm{~mm} /$ 24,4 mm / 1,63 mm), 4T1 (with parameters $L / t_{c} / t_{s}-$ $298 \mathrm{~mm} / 19,1 \mathrm{~mm} / 1,63 \mathrm{~mm}$ ) and 1I1 (with parameters $L / t_{c} / t_{s}-2004 \mathrm{~mm} / 20,1 \mathrm{~mm} / 1,65 \mathrm{~mm}$ ) are selected to demonstrate a typical failure mode of the specimens tested under ambient conditions (shown in Fig 4). Measuring the horizontal displacement of long HC-FST specimens in their middle height results in a very insufficient displacement, which cannot be related to the beginning of the overall buckling of the specimen. The values of the longitudinal and transversal strains measured at the surface of the steel shell of the HC-FTS specimens in relation to $N_{t} / N_{u}$ are given in Fig 5. The main parameters of the test are presented in Table 2 . The recorded mean values of normal ultimate stresses of the HC specimens $\sigma_{u . m}=45,44 M P a$. The mean normal ultimate stresses were calculated according to the formula:

$$
\sigma_{c r}=N_{c r} / A_{c}
$$

where: $N_{c r}$ - critical experimental load applied to the specimen; $A_{c}$ - the cross-section area of the concrete core of the specimen. According to $[12,13]$, the ring strength 
of the concrete can be equated with specific compressive prism strength of concrete $-f^{\prime}$ c.m.

The mean trial limit value of steel yield was $f_{y . m}=$ $318,3 \mathrm{MPa}$, whereas the mean trial limit value of steel strength was $f_{u . m}=358,3 \mathrm{MPa}$.

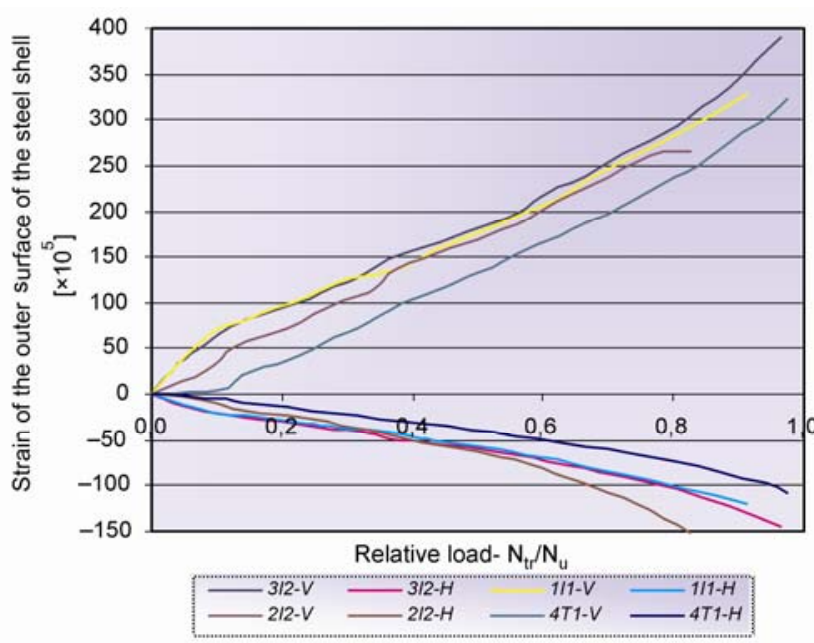

Fig 5. Experimental longitudinal and transversal strains of the steel shell of the HC-FST specimen in relation to the relative load $N_{t r} / N_{u}$, measured during the test under ambient conditions

\subsection{Fire resistance determination - fire resistance test}

The equipment for fire resistance test. 4 long $\mathrm{HC}$ FST specimens were prepared for testing. The specimens were tested under compressive axial load, and simultaneously supplying heat to them (simulated working of the building structure under the fire conditions). An electric "Utena 1" heating furnace was used for heating. The specimen and the furnace were placed on the lower support plate of the press. For avoiding additional heat losses through non-insulated points of the specimen and obtaining a more uniform distribution of temperature along the construction, the specimen ends protruding from the heating chamber of the furnace (at the top and bottom) were covered with a mineral wool mat of $50 \mathrm{~mm}$ thick. At one end of the specimens notches were made, which formed openings with the cross-section area $-0,25 \mathrm{~cm}^{2}$. The openings function was to let water steam that got formed in the inner cavity of the specimen and the concrete of the core during the heating escape. The furnace temperature was measured by stationary platinum-rhodium thermocouples and by using a portable furnace thermocouple connected to the universal data acquisition system ALMEMO 5590-1. Three stationary furnace thermocouples were installed in the heat-insulating layer of kaolin wool in one of the walls of the heating chamber (at the upper, middle and lower zones of the heating chamber).

Table 2. Main parameters of the test

\begin{tabular}{|c|c|c|c|c|c|c|}
\hline No & Type of the cross-section & Code of the specimen & Type of the tests & $\begin{array}{c}\mathrm{N}_{\mathrm{utr}} \\
{[\mathrm{kN}]}\end{array}$ & $\begin{array}{c}\mathrm{t}_{\max } \\
{\left[{ }^{\circ} \mathrm{C}\right]}\end{array}$ & $\begin{array}{c}\mathrm{T} \\
{[\mathrm{min}]}\end{array}$ \\
\hline 1 & HC-FST & $1 \mathrm{II}$ & $\mathrm{I}$ & 62,5 & - & - \\
\hline 2 & HC-FST & $22 \mathrm{I}$ & $\mathrm{I}$ & 69,0 & 0 & 0,0 \\
\hline 3 & HC-FST & $32 \mathrm{I}$ & $\mathrm{I}$ & 74,5 & - & - \\
\hline 4 & HC-FST & $5 \mathrm{I} 1$ & $\mathrm{I}$ & 72,5 & - & - \\
\hline 5 & HC-FST & 0T1 & $\mathrm{I}$ & 60,5 & - & - \\
\hline 6 & HC-FST & $1 \mathrm{~T} 1$ & $\mathrm{I}$ & 98,0 & - & - \\
\hline 7 & HC-FST & $2 \mathrm{~T} 1$ & $\mathrm{I}$ & 86,0 & - & - \\
\hline 8 & HC-FST & $2 \mathrm{~T} 2$ & $\mathrm{I}$ & 94,0 & - & - \\
\hline 9 & HC-FST & 3T1 & $\mathrm{I}$ & 75,5 & - & - \\
\hline 10 & HC-FST & 3 TI2 & $\mathrm{I}$ & 55,0 & - & - \\
\hline 11 & HC-FST & $4 \mathrm{~T} 1$ & $\mathrm{I}$ & 86,0 & - & - \\
\hline 12 & HC-FST & $5 \mathrm{~T} 1$ & I & 81,0 & - & - \\
\hline 13 & $\mathrm{HC}$ & 0TB2 & I & 63,5 & - & - \\
\hline 14 & $\mathrm{HC}$ & 1TB2 & $\mathrm{I}$ & 37,0 & - & - \\
\hline 15 & $\mathrm{HC}$ & $4 \mathrm{~TB} 2$ & I & 30,0 & - & - \\
\hline 16 & $\mathrm{HC}$ & $5 \mathrm{~TB} 2$ & I & 54,2 & - & - \\
\hline 17 & HC-FST & $0 \mathrm{I} 1$ & II.1 & 25,0 & 1020 & 59,4 \\
\hline 18 & HC-FST & 02I & II. 2 & 18,0 & 920 & 29,8 \\
\hline 19 & HC-FST & $2 \mathrm{I} 1$ & II.1 & 25,0 & 1190 & 37,0 \\
\hline 20 & HC-FST & $42 \mathrm{I}$ & II.1 & 25,0 & 1244 & 51,0 \\
\hline
\end{tabular}




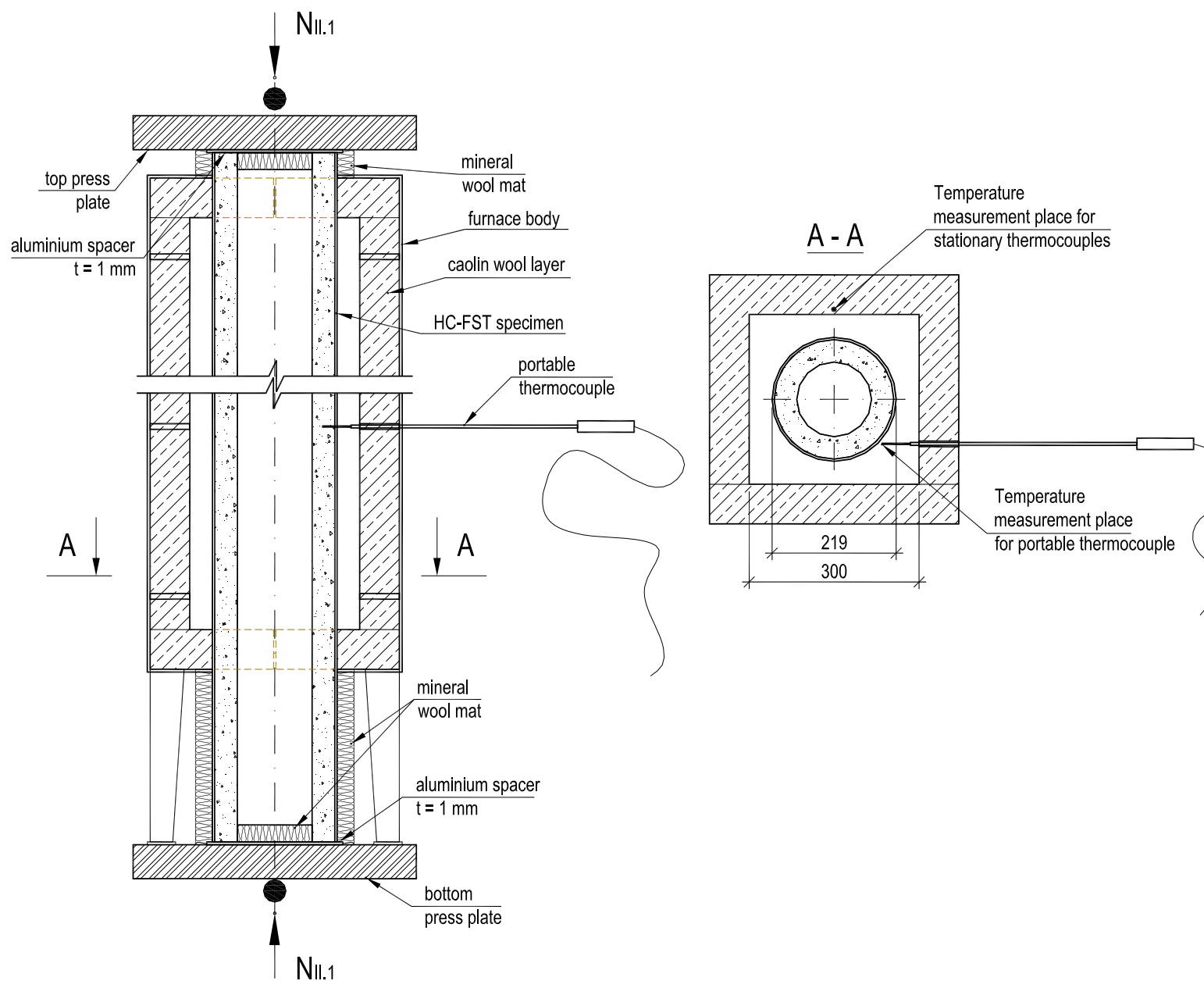

Fig 6. Specimen installation scheme for testing under elevated temperatures

The measuring accuracy of the stationary furnace thermocouples was $5^{\circ} \mathrm{C}$ within the measuring range over $300{ }^{\circ} \mathrm{C}$. The measuring accuracy of the portable thermocouple was $0,1{ }^{\circ} \mathrm{C}$ within the measuring range 0 to $1200^{\circ} \mathrm{C}$.

The trial temperature regime of the furnace was maintained using a 3-channel programmable temperature controller "PROTERM-100". The function of the temperature controller is to maintain the trial temperature regime uniform within all the levels of the furnace (lower, middle and upper). During the test all the efforts were made to maintain the temperature regime as close as possible to the standard fire regime stated in ISO-834. The scheme of the specimen installation is in Fig 6.

The process and measuring of type II test. The purpose was to determine the fire-resistance of the specimen, ie the time within which the construction reaches its ultimate state under the fire temperature conditions. For three of the four HC-FST specimens, the selected compressive load value was 25 ton, ie approx $40 \%$ of the mean loadbearing capacity of the specimens tested under normal conditions, whereas for one of 4 specimens an 18-ton axial load was applied. Following the specimen centring procedure, the specified load was applied to the specimens, and then the heating procedure was commenced, ie the time relay of the furnace temperature controller started. The preliminary compression of a specimen was carried out by raising it with the lower press plate, onto which the furnace body and the specimen rested.

The furnace temperature controller was programmed in such a manner that the mean temperature of the furnace was close to the standard (according to ISO-834) temperature - time curve, the analytical expression of which is given in formula 2 .

$$
t=345 \log _{10} \cdot(8 T+1)+20
$$

where $t$ - the mean temperature of the furnace in degrees Celsius; $T$ - time in min.

The standard temperature-time curve (according to ISO-834) and the curves of the temperature regime created during the test in the most heated point of the furnace are given in Fig 7.

Due to a high temperature, it was not possible to carry out measuring the deformations of the specimens on the steel shell surface. However, the behaviour of the specimen and the abundance of the production of the water steam were monitored throughout the test. The temperature measured by stationary thermocouples was recorded every $5 \mathrm{~min}$ and by the portable thermocouple was recorded every $30 \mathrm{sec}$. Most of the time, the portable thermocouple was inserted into the test chamber at its middle. The curves with code descriptions of the specimens 


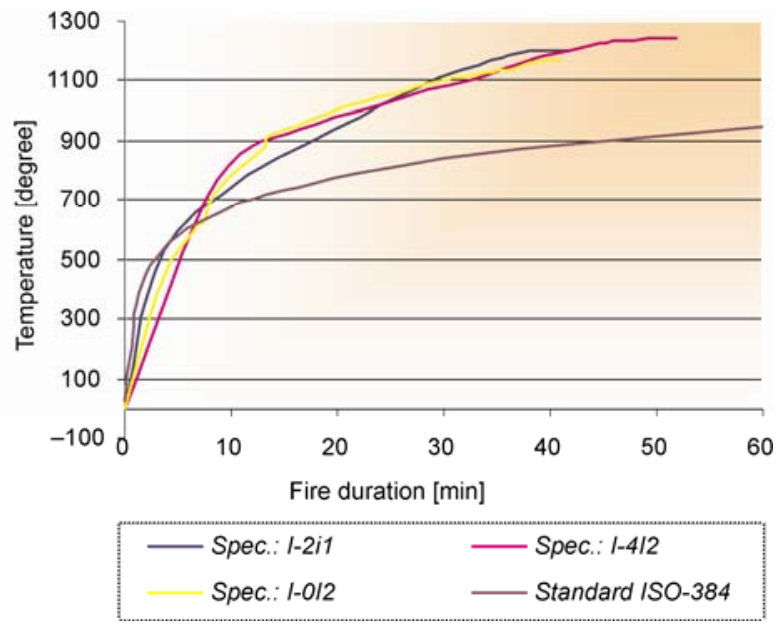

Fig 7. Furnace heating regime during the $1^{\text {st }}$ stage or the test type II.1

were obtained on the basis of furnace (in the most heated chambers place) temperature measuring readings during the testing of corresponding specimens. At a later time, the local buckling of the specimen would occur at this place or in its vicinity. The curves given in the diagram show that after 7 min from the start of testing the temperature in the most heated zone of the furnace was higher than the temperature according to the standard fire curve.

Experimental results and the failure mode after the test at elevated temperatures. As an experimental fire resistance of the specimen, the time from the start of the test to the specimen failure moment was taken. As the failure criterion for the fire resistance test, the moment at which the irreversible decreasing of load carrying capacity of the specimens began was taken.

Abundant production of water steam would start 7 min on average from the commencement of the test (when the mean temperature of the heating chamber of the furnace would reach $550{ }^{\circ} \mathrm{C}$ ), and it would cease approx $30 \mathrm{~min}$ on average after the test commencement. Insignificant production of water vapour continued throughout the test. In the most heated zone of the furnace, the steel shell of some specimens would buckle local-

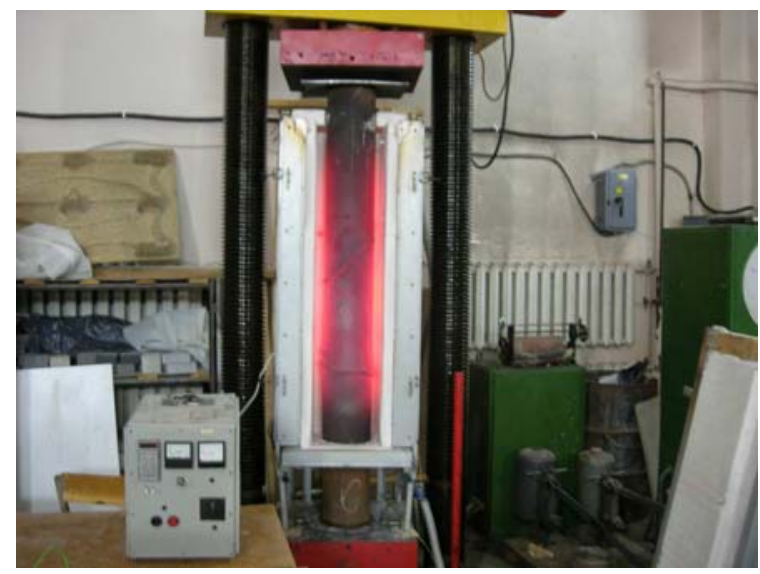

a)

Fig 8. A specimen during the test of Type 2: a) HC-FST specimen during the test; b) HC-FST specimen after test ly within $25-45$ min from the start of the test. Due to this factor, the redistribution of stresses in the cross-section of the composite element occurs. Upon the reduction of longitudinal stresses in the steel shell, the longitudinal deformation of the element increased considerably. The same phenomenon was recorded evidently due to a visibly increased stroke of the press required to maintain a load of the same quantity. In certain cases, the sound of the buckling steel shell could be heard.

The maximum temperature in the heating chamber of the furnace during the test was as high as $1240{ }^{\circ} \mathrm{C}$. The failure mode of the specimens was not a typical failure mode of overall buckling of long elements, viz columns. The failure mode of the specimens can be described as the loss of load-bearing capacity following the local buckling of the thick-walled steel shell and the concrete core, at the most heated point of the specimen or in its vicinity. The principal recorded parameters of the test are given in Table 2.

The specimens $4 \mathrm{I} 2$ (with parameters $\mathrm{L} / \mathrm{t}_{\mathrm{b}} / \mathrm{t}_{\mathrm{s}}-$ $2000 \mathrm{~mm} / 33,7 \mathrm{~mm} / 1,63 \mathrm{~mm}$ ) and 0I1 (with parameters $\mathrm{L} / \mathrm{t}_{\mathrm{b}} / \mathrm{t}_{\mathrm{s}}-1000 \mathrm{~mm} / 27,2 \mathrm{~mm} / 1,60 \mathrm{~mm}$ ) are selected to demonstrate the typical failure mode of the specimens tested under fire conditions (Fig 8).

It is not dimensional parameters, but it was apparently seen that the colour of the steel shell had a rosy shade and the weight of the specimens decreased significantly after testing.

\section{Estimation of the study results}

The following in-place tests of round thick-walled steel columns with a hollow thick-walled concrete core were carried out: determination of specimen resistance to axial compression under ambient $\left(t=20^{\circ} \mathrm{C}\right)$ conditions and determination of fire resistance of specimens (time until collapse under heat conditions). The behaviour of the specimens observed during the tests coincides with data supplied by a number of other researchers. Not all the results of the experiment are suitable for statistical procession; however, they make it possible to carry out analytical comparison of certain parameters and formulate corresponding conclusions.

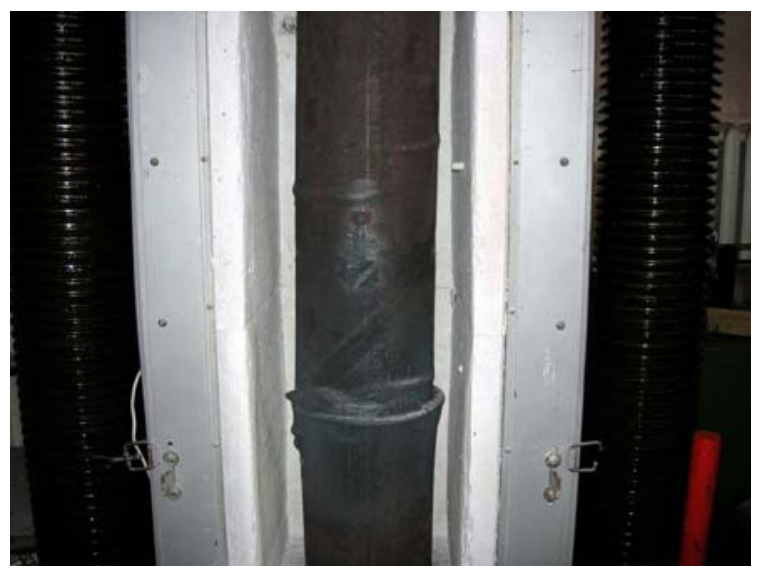

b) 
The mean trial fire resistance of HC-FST columns tested by loading them with $40 \%$ of their mean trial loadbearing capacity under normal conditions and heated according to a temperature curve close to the standard temperature curve was 44,3 $\mathrm{min}$. The maximum fire resistance observed during the test was $59,4 \mathrm{~min}$. The maximum temperature reached inside the heating chamber of the furnace was $1240{ }^{\circ} \mathrm{C}$.

The comparison of the fire resistance calculation results with the results of experimental research presented in this paper is given in [14]. Three times less load bearing capacity was received using a simple calculation model accordingly [15] than it was obtained during the experimental investigation.

During the test under normal and heating conditions both - short and long HC-FST elements lost their loadbearing capacity following a local buckling of the steel shell and the concrete core. During the type I test, the observed failure mode was predetermined by the thin walls of the steel and concrete parts of the cross-section, as well as the forces of friction between the supporting plate of the press and the end of the specimen. During the type II test, the observed failure mode was predetermined by the thin walls of the steel and concrete parts of the cross-section, as well as the uneven temperature of the specimens along the central axis. The failure of the specimen was observed in all instances at the zones of the specimens that were the most heated, during the test. The measured longitudinal and transversal strain values cannot be compared directly because specimens with unequal geometrical indices for the cross-sections, at which the strain-gauge transducers were attached to the surface of the steel shell were used. A relatively wide dispersion of the other test results can be accounted for: by a great number of the parameters that influence the results, due to imperfections of the test equipment, due to inaccuracies of the maintenance of the programmed temperature regime of the furnace, due to potentially different moisture of the concrete of the specimen core, due to regular dispersion of mechanical strength indices of the materials, ie steel and concrete and some other factors.

The calculation of temperature distribution in the section of the column under testing presented in [14] showed the temperature magnitude of a concrete core 10$15 \%$ less than temperature inside the furnace chamber during heating. It is seen that the calculated value of the temperature distribution (neglecting the water existence within the concrete core) is not adequate to the experimental data as the water steam was clearly observed for $30 \mathrm{~min}$ from the beginning of the heating. The temperature distribution in the cross-section of HC-FST column after 45 min from the beginning of the standard fire [16] calculated by FEM modelling shown in Fig 9.

It is given in [17] that the design compressive strength of concrete heated to $800{ }^{\circ} \mathrm{C}$ may amount to its $16 \%$ of initial strength, and the strength of the steel heated to $900{ }^{\circ} \mathrm{C}$ may amount to its $6 \%$ of initial strength. Compressive resistance of the CHS columns (with the mean geometrical and mechanical properties of steel shell of the tested HC-FST specimens) under ambi- ent conditions was determined from calculations according to $[17,18]$ and makes up $-302,6 \mathrm{kN}$.

The analysis of the compressive resistance of the same CHS column under fire conditions was made as well. Compressive resistance of the CHS column under fire conditions after $45 \mathrm{~min}$ of heating was obtained as the result of calculation according to [19] and makes up only $18,02 \mathrm{kN}$.

The compressive resistance of the HC-FST column with geometrical parameters of the tested specimens (from Table 1) in ambient temperatures calculated according to [20] makes up $635 \mathrm{kN}$ and it is quite close to an experimental mean value $696 \mathrm{kN}$.

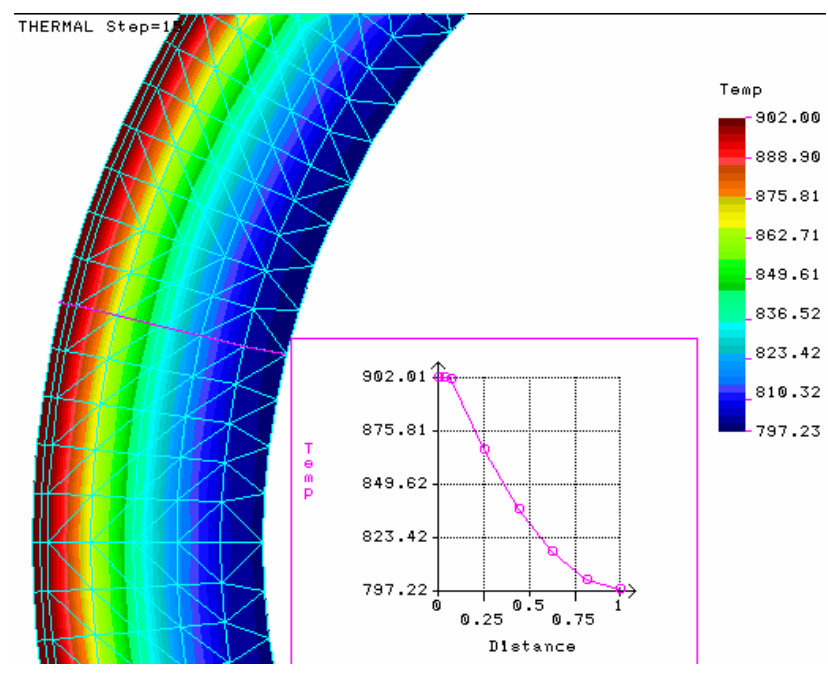

Fig 9. Temperature distribution in the cross-section of the HC-FST column after $45 \mathrm{~min}$ from the standard fire beginning

By the analysis of experimental results and calculation results it can be stated that the greater portion of the load applied to the CH-FST column is taken by a concrete core in a fire situation.

\section{Conclusions}

1. The influence of temperature on the compressive resistance of HC-FST specimens is immense. However, the necessary fire resistance of concrete filled hollow steel section columns can generally be achieved without any fire protection covers.

2. The mean trial fire resistance of HC-FST columns tested by loading them with $40 \%$ of their mean trial loadbearing capacity under normal conditions and heated according to the temperature curve close to the standard temperature curve was 44,3 $\mathrm{min}$. On the basis of the analysis of test results and by taking into account that according to [21] the calculating load of the constructions of the most civil buildings under fire conditions makes up approx $40 \%$ of the calculating load under normal $\left(t=20{ }^{\circ} \mathrm{C}\right)$ conditions, it can be stated that HC-FST elements designed for the use at ambient temperature always meet construction fire resistance class RE30, and in some cases - fire resistance class RE45. 
3. The observation of the behaviour of the HC-FST specimens in fire under axial compression allows to expect not a sudden failure mode via the overall buckling of HC-FST columns but the failure mode that could be described as local buckling of the thin-walled steel shell and local failure of the hollow concrete core.

4. From the water steam emission observation it can be stated that the temperature distribution in the section of columns during testing is substantially influenced by the availability of free and chemically combined water in the concrete core of HC-FST element. Water inside the concrete should be always taken into account when calculating the temperature distribution in the cross-section of the HC-FST column under heat conditions.

5. The concrete core takes the greater part of the axial load applied to the CH-FST column during the fire but the steel shell is not very well resisting the normal stresses under fire.

\section{References}

1. ŠAPALAS, A. Composite and interaction effect in steelconcrete structures for higher fire resistance. Journal of Civil Engineering and Management, 10(3), 2004, p. 241245.

2. COLINA, H.; MOREAU, G. and CINTRA, D. Experimental study of transient thermal creep and other phenomena of concrete at high temperature. Journal of Civil Engineering and Management, 10(4), 2004, p. 255-260.

3. HAN, L.-H.; ZHAO, X.-L.; YANG, Y-F. and FENG, J.-B. Experimental study and calculation of fire resistance of concrete-filled hollow steel columns. Journal of Structural Engineering, 129(3), 2003, p. 346-356.

4. SHAKIR-KHALIL, H. and AL-RAWDAN, A. Experimental behaviour and numerical modelling of concretefilled rectangular hollow section tubular columns. In Proc of an engineering foundation conference composite construction in steel \& concrete III, Irsee, Germany, June 914, 1996. Ed C. D. Buckner and B. M. Shahrooz, American Society of Civil Engineers, 1997, p. 222-235.

5. BLAŽEVIČIUS, Ž. and KVEDARAS, A. K. Comparison of the fire design calculation for composite concrete filled CHS columns. In Proc of the 8th International Conference „Modern Building Materials, Structures and Techniques “, Vilnius, Lithuania, May 19-22 2004. Selected papers, ed E. K. Zavadskas, P. Vainiūnas and F. M. Mazzolani. Vilnius: Technika, 2004, p. 357-362.

6. KODUR, V. Achieving fire resistance in steel columns through concrete filling. Concrete Engineering International, 8(4), 2004, p. 50-53.

7. TAN, K-H. and TANG, C.-Y. Interaction model for unprotected concrete filled steel columns under standard fire conditions. Journal of Structural Engineering, 130(9), 2004, p. 1405-1413.
8. AL-KHALEEFI, A. M.; TERRO, M. J.; ALEX, A. P. and WANG, Y. Prediction of fire resistance of concrete filled tubular steel columns using neural networks. Fire Safety Journal, 37(4), 2002, p. 339-352.

9. LST EN 10002-1:2003 - Metallic materials. Tensile testing. Part 1: Method of test at ambient temperature. Lithuanian Standards Board. Vilnius, 2003. 56 p.

10. LST EN 1363-1:2000. Fire resistance tests. Part 1: General requirements. Lithuanian Standards Board. Vilnius, 2000. 49 p.

11. LST EN 1363-1:2000. Fire resistance test of load bearing elements. Part 4: Columns. Lithuanian Standards Board. Vilnius, 2000. $10 \mathrm{p}$.

12. VADLŪGA, R. and KUDZYS, A. On the compressive strength of the centrifuged concrete. Researches on Reinforced Concrete Structures (Исследование nо железобетонным конструкциям), Vol 1, Vilnius: Mintis, 1966, p. 111-116 (in Russian).

13. KUDZYS, A. Reinforced concrete structures of annular cross-section (Железобетонные конструкции кольцевого сечения). Vilnius: Mintis, 1975. 224 p. (in Russian).

14. BLAŽEVIČIUS, Ž. and ŠAUČIUVĖNAS, G. The course of an experimental research on the fire resistance of HCFST columns and the results of their calculation. In Proc of National Conference Building Structures - Development of building structures during integration in the space of Eurocodes, on 3rd of March 2006. Vilnius: Technika, 2006, p. 42-50 (in Lithuanian).

15. LST EN 1994-1-2:2006. Eurocode 4 - Design of composite steel and concrete structures - Part 1-2: General rules Structural fire design. Lithunanian Standards Board. Vilnius, 2006. 109 p.

16. EN 1991-1-2:2002. Eurocode 1 - Actions on structures. Part 1-2: General actions. Actions on structures exposed to fire. European Committee for Standardization. Brussels, Jan 2002. 59 p.

17. STR 2.05.08:2005. Desing of steel structures. General rules (Plieniniu konstrukcijų projektavimas. Pagrindinès nuostatos). Vilnius: Rekona, 2005. 95 p. (in Lithuanian).

18. EN 1993-1-1. Eurocode 3: Design of steel structures Part 1-1: General rules and rules of buildings. European Committee for Standardization. Brussels, May 2005. 91 p.

19. EN 1993-1-2. Eurocode 3: Design of steel structures Part 1-2: General rules - Structural fire design. European Committee for Standardization. Brussels, Apr 2005. 78 p.

20. LST EN 1994-1-1:2005. Eurocode 4 - Design of composite steel and concrete structures - Part 1-1: General rules and rules for buildings. Lithuanian Standards Board. Vilnius, $2005.118 \mathrm{p}$.

21. LST ENV 1991-1:2000. Eurocode 1 - Basis of design and action on structures - Part 1: Basis of design. Lithuanian Standards Board. Vilnius, 2000. 85 p. 


\section{CENTRIŠKAI GNIUŽDOMŲ HC-FST KOLONŲ ATSPARUMO UGNIAI EKSPERIMENTINIS TYRIMAS}

\section{Ž. Blaževičius, A. K. Kvedaras}

\section{Santrauka}

Yra sukurta keletas analitinių metodų vamzdinių plieno kolonų su betono šerdimi atsparumui kaitros sąlygomis nustatyti. Didžiuma šių analitinių metodų yra paremti arba buvo kuriami analizuojant eksperimentinių kaitrinių tyrimų duomenis. Buvo atlikti vamzdinių plieno kolonų su tuščiavidure betono šerdimi elgsenos kaitros sąlygomis eksperimentiniai tyrimai, matuojant skirtingus bandymo parametrus. Eksperimentiškai ištirta 16-kos centriškai gniuždomu HC-FST (centrifuguotų tuščiavidurių betonšerdžių plieninių vamzdinių) kolonų, nepadengtų apsauginèmis (atsparumą kaitrai didinančiomis) dangomis, elgsena kaitros sąlygomis (panašiomis i ISO-834 standartini gaisra), ir tyrimo rezultatai yra pateikti šiame straipsnyje. Nustatytos 4-ių centriškai gniuždomų HC-FST kolonų atsparumo kaitrai eksperimentinès reikšmès ir suirimo pobūdis. Bandymu parametrams palyginti buvo išbandytos 4-ios centriškai gniuždomos HC-FST kolonos normaliomis sąlygomis, taip pat centrišku gniuždymu buvo išbandyti 8 HC-FST trumpi elementai ir 4 betoniniai žiedai normaliomis sąlygomis. Pagrindiniai straipsnyje aprašyto tyrimo tikslai - gauti eksperimentinių duomenų analizei ir priklausomybėms tarp bandymo parametrų, darančių didžiausią itaką HC-FST kolonų atsparumui kaitrai, išvesti.

Reikšminiai žodžiai: eksperimentinis tyrimas, ašinė apkrova, betonšerdès plieninès vamzdinès kolonos, laikomoji galia, atsparumas ugniai.

Žygimantas BLAŽEVIČIUS. MSc (CE), PhD student from 2002 at the Dept of Steel and Timber Structures of Vilnius Gediminas Thechnical University. Field of research: composite steel-concrete structures, their fire resistance.

Audronis Kazimieras KVEDARAS. Professor, Doctor Habil, Head of Dept of Steel and Timber Structures and Director of the Innovatory Scientific Institute of Special Structures „Kompozitas“ of Vilnius Gediminas Technical University. Field of research: steel structures and composite steel-concrete and timber-concrete structures. Member of IABSE and ASCCS, invited NATO expert (1996, 2000). 